\title{
Extension Management Competency Needs of Agricultural Extension Agents in Kenya
}

\author{
Mary Lopokoiyit
}

Department of Agricultural Education and Extension

Egerton University, KENYA

email: mclopokoivit@yahoo.com

Alternative email: mclopokoivit@egerton.ac.ke

\section{Prof. Christopher Onyango}

Department of Agricultural Education and Extension,

P.O. Box 20115-536, Egerton University

Email: onyangochristopher6@gmail.com, Tel: 0722-902908

\section{Dr. Joash K. Kibett}

Department of Agricultural Education and Extension, P.O. Box 20115-536, Egerton University

Email: kibettjoash@yahoo.com / jkibett@egerton.ac.ke, Tel: 0726-097186

\author{
Doi:10.5901/mjss.2013.v4n6p11
}

\begin{abstract}
Improvement in the management of agricultural extension organizations has been identified as a key challenge in the delivery of extension services in Kenya. Ensuring effective management of agricultural extension services is crucial to the growth of the agricultural industry. To improve extension service delivery, the Agricultural Sector Development Strategy (ASDS) has been formulated with a paradigm shift from a top-bottom and centralized extension service to a decentralized and pluralistic extension service. Training staff to acquire capabilities to operate under these new management models is critical to the revitalization of the agricultural industry which is a key economic growth strategy in the Vision 2030. This requires an assessment of the management competencies required by extension staff in order to make recommendations for appropriate design of training programmes. Based on this premise, this study was conducted to examine the current extension management competencies of 440 staff in the public and private agricultural extension service sectors and assess differences in competency requirements between Frontline Extension Workers (FEW) and Subject Matter Specialists (SMS). A crosssectional survey was used and training needs determined and expediency prioritized using Borich's Needs Discrepancy Model (BNDM) and a Mean Weighted Discrepancy Score (MWDS). The agricultural extension management competencies with the highest training need were; Motivating employees, Stress management, Managing conflict, Strategic planning, Mentoring/coaching employees, and Employee appraisal and counselling. Management competencies such as communication, extension program management and farmer group formation were also prioritized for training. There were no significant differences between the training needs of extension agents in the sectors and only managing finances was significantly different between SMS and FEW. The high MWDS obtained for management competencies form the basis for designing relevant in-service courses and warrant their inclusion in agricultural programs at the undergraduate and postgraduate levels.
\end{abstract}

Keywords: Agricultural extension, Competencies, Training needs, Management

\section{Introduction and Background to the Study}

Agriculture, the mainstay of Kenya's economy, currently contributes 26 per cent of the GDP directly and another 25 per cent indirectly. The sector also accounts for 65 per cent of Kenya's total exports and provides more than 18 per cent of formal employment. More than 70 per cent of informal employment is in the rural areas (GoK, 2010). The role of the agricultural sector in Kenya is of great importance because it directly influences the country's economic growth and will 
continue to feature prominently in the country's development agenda as a basis for food security, employment creation and foreign exchange generation (GoK, 2010). Vision 2030 has identified agriculture as one of the key sectors to deliver the 10 per cent annual economic growth rate envisaged under the economic pillar. To achieve this growth, transforming smallholder agriculture from subsistence to an innovative, commercially oriented and modern agricultural sector is critical (GOK, 2010). The development of an efficient agricultural sector stimulates the national and rural economy by improving incomes, food security and living standards and this is the role of the national extension system (GOK, 2008). As a means of appropriate technology generation and dissemination to the farming community, agricultural extension serves the role of facilitating this contribution.

This study was designed to identify extension management competency needs of agricultural extension personnel in Kenya in light of changing trends in agriculture production, extension strategies and environmental concerns that have implications on the way extension workers are trained. Identifying these needs is important to ensure that the curriculum addresses the needs of both the public and private extension service providers. It also forms a basis for reviewing the curricula to ensure that training is relevant, demand driven and responsive to the dynamic agricultural sector. This will also reassure stakeholders that the knowledge, skill and attitudes that graduates develop will be meaningful to their future employment goals.

\section{The Changing Context of Agricultural Extension Service in Kenya}

The extension system through the late 1990's has been plagued with poor management and diminishing funding resulting in inefficiency, ineffectiveness and non-delivery of services (Evenson and Mwabu, 2001; Republic of Kenya, 2001) resulting from the changing internal and external environments and the structural adjustment program instituted by the World Bank and International Monetary Fund (IMF) had a major impact on the organizational, institutional and manpower aspects of the national agricultural extension service. These factors contributed to a decline in agricultural growth from an average of $4.6 \%$ per annum in $1964-1973$ to $0.4 \%$ in $1990-1995$ and a merger $1.1 \%$ in $1999-2000$ (Republic of Kenya, 2001). To reverse and revamp the negative trend in extension service delivery, the Ministry of Agriculture and Rural Development (MOARD) formulated the National Agricultural Extension Policy (NAEP) to guide implementation of appropriate actions under the National Agriculture and Livestock Extension Programme (NALEP). This led to a pluralistic extension model in which the government takes the role of a facilitator for many other groups involved in extension (McMillan, Husein \& Sanders, 2001; Republic of Kenya, 2000; Republic of Kenya, 2001). The extension policy in Kenya was redefined further through the Strategy for Revitalizing Agriculture (SRA) as part of the Economic Recovery Strategy for Wealth and Employment Creation (ERSW\&EC) with the objective of modernising agriculture, improving research and extension services, promoting partnerships, and accountability for efficient extension service. The Agricultural Sector Development Strategy (GOK, 2010) aims to achieve an average growth rate of 7 per cent per year over the next 5 years. To deliver the vision of the agricultural sector, institutional reforms and better coordination will be critical.

The move towards privatization, demand-driven, grass-root, bottom-up approaches and decentralization has focused planning, implementation and coordination of extension activities at the district, divisional level and local level initiatives. The district is the government's development planning unit where funds are disbursed and managed by the District Agricultural Officer (DAO) while the division is the implementation level (Republic of Kenya, 2001; MOARD, 2000). The DAO provide technical backup and staff training through subject matter specialists (SMS) to the divisional level staff who in-turn train Frontline Extension Staff (FEW) and Technical Assistants (TA). The divisional level staff undertake individual farm visits, advise community and farmer groups and assist in the development of Focal Area Development Plans (FADP) and Farm Specific Action Plans (FSAP), organize field days, and facilitate participatory learning, consultation and technical training (MOARD, 2000). The responsibility for extension service therefore lies with the district and more heavily on the divisional teams. The decentralization of extension service provision further emphasizes the need for extension staff to have additional skills, in technical areas, communication skills (written, oral, computer and internet use skills), leadership, management and personal skills at all management levels. Most extension workers have been trained as crop or livestock specialists and have little or no training in the social sciences; therefore, most are not trained in how to organize farmers into producer groups or other types of farmer organizations (Cho and Boland, 2004; Swanson, 2008). Buford, Bedeian, and Lindner, (1995) found that agricultural agents need to possess relevant managerial behavioural dimensions that include oral communication, planning/organizing, leadership, decision making/judgment, initiative, objectivity, development of co-workers, perception, sensitivity, management control, collaborativeness, written communication, behavioural flexibility, organizational sensitivity, and assertiveness. 


\section{Agricultural Extension Management}

Managers in extension are engaged in four main types of activities, namely; building and maintaining relationships, getting and giving information, influencing people, and decision making. Mintzberg (1973) categorised management work into three categories with ten roles that fall within established management functions of planning, organizing, staffing, directing, coordinating, reporting and budgeting. Whiteside (1998) outlines the essential managerial behaviour dimensions for agricultural extension managers (county chairs) to include communication, public relations, leadership, planning, image building, budget accountability, decision making, evaluation, staff support, and motivation. Sleezer et. al., (2000) in a study to determine priority management, training needs of extension agents identified were in management/leadership skills and personal development. Since extension almost exclusively recruits its managers from within, unlike commercial or manufacturing businesses, it is important that along technical skills they need to be trained in management competencies.

In response to the low level of management skills of extension managers in Africa, the Agricultural Management Training Programme for Africa (AMTA) was initiatedby IFAD in the early 1980s and conducted in collaboration with the African Development Bank (AfDB), the World Bank's Economic Development Institute (EDI), and the Organization of African Unity/Scientific, and the Technical and Research Commission (OAU/STRC) (IFAD, 2006). An evaluation of the training found that trainees expressed satisfaction with monitoring and evaluation team-building methods and Performance Improvement Planning (PIP) but were dissatisfied with the general treatment of substantive topics such as financial management, agricultural credit, extension, and procurement. This was attributed to a combination of factors such as; the shortage of trainers with sufficient expertise in these subjects, knowledge gaps between theory and applicability and the difficulties in satisfying the expectations of a heterogeneous group of participants from many countries. This was also expensive and not sustainable considering the number of agricultural workers requiring training in Africa (IFAD, 2006). Lindley (1999) argues that in-service education should not be used to make up for what should have been learned at the pre-service level and that the available time to learn about new things is reduced and the value of in-service training is diminished in the work place. This study therefore sought to identify and prioritise extension management training areas across public and private extension sectors for up scaling into the undergraduate agricultural curricula and contribute toward closing the gap between the actual and needed curriculum and between formal training and the world of work.

\section{Objectives and Hypotheses of the Study}

The purpose of this study was to identify agricultural extension management training needs of extension agents in public and private extension organizations in Kenya. The following hypotheses were tested.

1. There is no statistically significant difference in agricultural extension management training competenciesof public and private extension service providers.

2. There is no statistically significant difference in agricultural extension management training competenciesof Frontline Extension Workers (FEW) and Subject Matter Specialists (SMS).

\section{Population and Sampling}

The study involved multistage sampling; first through purposive sampling of nine districts and private extension organizations and secondly, of 5,100 staff under the Ministry of Agriculture (MoA) and the Ministry of Livestock Development (MoLDF) and private extension organizations in the study districts. A total of 440 extension agents were sampled; 325 from the public sector and 115 from the private extension service. Data on current competencies and training needs of the extension staff were obtained using a questionnaire designed to solicit demographic data and rating scales on the importance, knowledge and opportunity to use ratings. The data collected were analyzed using descriptive and inferential statistics.

The following counties were used in the study and formed the accessible population; Machakos, Bungoma, TransNzoia, Uasin-Gishu, Elgeyo-Maraket, and Kilifi drawn from four provinces as shown in Table 1. These districts have different agro-ecological zones and diverse agricultural activities and ensured that the study captured the different challenges facing extension workers. Extension workers in the study had a minimum diploma in an agricultural related discipline. 
Table 1: Distribution of respondents by province

\begin{tabular}{lcc}
\hline Location of Study & Frequency & Percent \\
\hline Rift Valley Province & 153 & 34.8 \\
Coast Province & 89 & 20.2 \\
Eastern Province & 69 & 15.7 \\
Western Province & 129 & 29.3 \\
\hline Total & 440 & 100.0 \\
\hline
\end{tabular}

\section{Instrumentation and Research Model}

Two sets of questionnaires were to collect data in this study. The first questionnaire was designed to collect demographic data of the respondents and the second section of the questionnaire sought to solicit information on training needs in leadership and management competencies. The study used Borich's Needs Discrepancy Model (1980) that effectively lends itself to the standard survey questionnaire to collect information and has the added advantage of yielding more data by determining areas in which are of importance and therefore needed, while knowledge rating indicate proficiency in the area (Edwards and Briers, 1999). The items were on a five point Likert scale indicating the level of importance, knowledge and opportunity use, enabling training need to be calculated and prioritized using the Mean Weighted Discrepancy Score (MWDS). According to Joerger (2002), Borich's model can be used to compare training needs within and between different groups by subjecting the median scores and MWDS to further analyses. The study used the modified model to include opportunity of use score to further refine the level of need.

Educational Need $=(\mathrm{I}-\mathrm{K} \times \mathrm{I})+[(\mathrm{I}-\mathrm{O}) \times \mathrm{I}] / 2$

Where, I is the importance score; $\mathrm{K}$, the knowledge score, and $\mathrm{O}$, the opportunity score.

Each section had additional open-ended questions soliciting further views on the various items. The mean weighted discrepancy score (MWDS) was then calculated from the ratings to derive training need. The MWDS was also used to rank the training needs. All hypothesis tests were done at $5 \%$ level of significance $(\alpha=0.05)$.

A critical incident questionnaire was also administered using the Critical Incident Technique (CIT) in which the respondents identified critical incidents in extension work judged to be important and the identification of actual behaviour, which lead to the success or failure of the activity (Flanagan, 1954). The implications for training were derived from the behaviours extracted from the critical incidents. These are analyzed, formulated into concepts and sub concepts that were the knowledge gap or need to be met (Craig, 1992).

\section{Results and Discussions}

Subject Matter Specialists (SMS) had a minimum professional qualification of a degree in an agricultural related discipline and constituted 38.4 percent $(n=169)$. The highest level of qualification was at PhD level $(n=4)$ and Masters level $(n=37)$. The large number of diploma holders, 61.6 percent, presents a potential for in-service training to upgrade their qualifications. These figures indicate the high level of qualified personnel in agricultural extension that could be partly attributed to employers' commitment to professional development. The respondents supervised an average of seven people with $\sigma=10.086$, indicating a need for human resource management competencies. The majority of extension staff were in their mid career stage as indicated by a mean age of 42.21 years $(\sigma=8.124)$. The number of years worked ranged from less than one year to 34 years with a mean of 16.13 years $(\sigma=9.289)$. The respondents had hardly changed employment ( $\bar{x}=0.62 ; \sigma=1.268$ ) and could be attributed to depressed employment opportunities in the agricultural sector and loyalty to their respective employers. A summary of the respondents' demographic characteristics is presented in Table 1. 
Table 1: Respondents' qualification, responsibilities and span of control

\begin{tabular}{|c|c|c|c|}
\hline \multicolumn{2}{|c|}{ Professional Characteristic } & Frequency & Percent \\
\hline \multicolumn{4}{|c|}{ Category of respondent and Qualification } \\
\hline FEW & Diploma & 271 & 61.6 \\
\hline \multirow[t]{5}{*}{ SMS } & & 169 & 38.4 \\
\hline & Degree & 128 & 29.1 \\
\hline & Masters & 37 & 8.4 \\
\hline & $\mathrm{PhD}$ & 4 & 0.9 \\
\hline & Total & 440 & 100.0 \\
\hline \multicolumn{4}{|c|}{ Time spent on Responsibility } \\
\hline & Administration & 290 & 15.0 \\
\hline & Field work & 420 & 51.1 \\
\hline & Seminars/workshops & 357 & 7.0 \\
\hline & Extension/advisory & 372 & 11.5 \\
\hline & Meeting & 395 & 9.6 \\
\hline & Other responsibilities & 157 & 6.0 \\
\hline \multicolumn{4}{|c|}{ Span of control } \\
\hline & 0 & 104 & 23.6 \\
\hline & $1-10$ & 246 & 55.9 \\
\hline & $11-20$ & 58 & 13.2 \\
\hline & $21-30$ & 13 & 3.0 \\
\hline & $31-40$ & 9 & 2.0 \\
\hline & 41 and more & 10 & 2.3 \\
\hline & Total & 440 & 100.0 \\
\hline
\end{tabular}

\section{Training competency needs in agricultural extension management}

Table 3 shows that all the MWDS were all positive with a mean of 5.15 . This implies that all the leadership and management competencies were important and the respondents required them for training. This also validates their presence in the agricultural undergraduate curriculum. The training need score (MWDS) presented in the last column of Table 3 shows that the Borich Needs Discrepancy Model (BNDM) ciphers competencies with the highest training need as; Motivating employees, Stress management, Managing conflict, Strategic planning and Management and administrative techniques. These courses are basic Human Resource Management competencies required of any manager and cross validates the findings on administration and extension responsibilities, span of control (Table 1). .

Strategic planning is a key component of the Public Service Reform and all government departments are required to develop Strategic Plans to guide action and increase accountability to stakeholders. Conflict management skills are not only necessary in the work place but also in dealing with conflict in the community over resources or in prioritizing extension activities. Conflicts in agriculture result from scarce resources, conflicting interests, cultural and political differences. Management and administrative techniques competencies were ranked highly with a MWDS of 5.99, underscoring the importance of management skills in extension work.

Career development planning and managing finances/budgeting ranked fifth and sixth in priority training needs. Fetsch and Kennington (1997) and Ensle (2005) found job stress to be a condition prevalent among extension agents and explained that the extension system is stressful and does not provide adequate technical support directly to extension agents at the district and divisional levels. Moreover, inefficiencies due to inadequate logistical and attendance of many committee meetings, contributed to job stress for extension agents. Summerhill and Arrington (2000) found factors such as over-commitment, continuous multi-tasking and working late as statistically related to the amount of stress an agent experienced. Extension activities are often intense job assignments, obligation to work irregular hours, and working with farmer groups and stakeholders with conflicting interests contributes to stress among extension staff (Strong and Hardy, 2009; Kutilek, Conklin, and Gunderson, 2002). 
Table 3: Training need in agricultural extension management competency

\begin{tabular}{lccccccc} 
Extension Management Competencies & \multicolumn{2}{c}{ Importance } & \multicolumn{2}{c}{ Knowledge } & \multicolumn{2}{c}{ Opportunity } & \multirow{2}{*}{ MWDS } \\
\cline { 2 - 6 } & $\mathbf{M}$ & SD & $\mathbf{M}$ & SD & $\mathbf{M}$ & SD & \\
\hline Motivating employees & 4.29 & 1.09 & 3.19 & 1.21 & 3.47 & 1.44 & 6.77 \\
Stress management & 4.25 & 0.99 & 2.85 & 1.21 & 3.44 & 1.34 & 6.77 \\
Managing conflict & 4.28 & 0.94 & 2.91 & 1.19 & 3.54 & 1.27 & 6.25 \\
Strategic planning & 4.34 & 0.92 & 2.94 & 1.17 & 3.67 & 1.28 & 6.17 \\
Management and administrative techniques & 4.28 & 0.96 & 2.93 & 1.19 & 3.65 & 1.30 & 5.99 \\
Career development planning & 4.03 & 1.11 & 2.86 & 1.19 & 3.26 & 1.33 & 5.93 \\
Managing finances/budgeting & 4.39 & 0.93 & 3.05 & 1.20 & 3.73 & 1.32 & 5.84 \\
Balancing personal/professional life & 4.19 & 0.97 & 3.02 & 1.20 & 3.66 & 1.21 & 5.58 \\
Employee appraisal and counselling & 4.22 & 1.07 & 3.17 & 1.21 & 3.57 & 1.38 & 5.44 \\
Problem solving & 4.46 & 0.80 & 3.28 & 1.09 & 3.93 & 1.08 & 5.30 \\
Decision making & 4.543 & 0.77 & 3.52 & 1.09 & 4.10 & 1.06 & 5.07 \\
Maintaining ethical standards & 4.32 & 0.93 & 3.35 & 1.20 & 3.89 & 1.13 & 5.05 \\
Negotiation skills & 4.15 & 0.98 & 3.05 & 1.17 & 3.67 & 1.19 & 5.00 \\
Mentoring/coaching employees & 3.96 & 1.14 & 3.00 & 1.19 & 3.40 & 1.30 & 4.91 \\
Prioritizing work & 4.53 & 0.76 & 3.62 & 1.05 & 4.10 & 1.06 & 4.82 \\
Community leadership development & 4.42 & 0.81 & 3.42 & 1.03 & 4.03 & 1.04 & 4.70 \\
Inter-agency collaboration/partnership & 4.31 & 0.90 & 3.39 & 1.01 & 3.96 & 1.06 & 4.39 \\
Time management & 4.611 & 0.71 & 3.781 & 1.05 & 4.302 & 0.97 & 4.34 \\
Team building & 4.543 & 0.74 & $3.65^{3}$ & 0.98 & 4.273 & 0.89 & 4.11 \\
Leadership skills & $4.58^{2}$ & 0.69 & $3.72^{2}$ & 0.93 & $4.32^{1}$ & 0.84 & 3.98 \\
Delegating responsibility & 4.14 & 0.92 & 3.48 & 1.00 & 3.76 & 1.13 & 3.73 \\
\hline Overall mean score & 4.34 & $\mathbf{0 . 9 0 5}$ & 3.17 & 1.154 & 3.76 & 1.18 & $\mathbf{5 . 1 5}$ \\
\hline n= 440 & & & & & & &
\end{tabular}

\section{Comparison of Management and Leadership Competencies needed by Extension agents from the Public and Private Extension Service}

Table 4 shows that the mean MWDS ratings for the Public sector was higher than that of the Private sector. However, the relatively high MWDS obtained across all the competencies for both the Public and Private sector suggest a high training need. Strategic planning, Management and administrative techniques and Career development planning were significantly different with the Public sector registering higher training needs in these competencies. This may be attributed to a larger span of control in terms of staff numbers in the public sector as opposed to the Private sector. The Districts and divisions being the centers of work demands more management responsibility devolved and therefore the expressed training needs.

Increased emphasis on corporate governance and improved management of public institutions may also contribute to the observed training needs. The discussion on leadership competencies can be perceived in two ways. First, leadership competencies in dealing with internal stakeholders, that is, agricultural staff and support staff and secondly, providing leadership to external stakeholders such as farmers. Table 4 clearly shows that although scores on Motivating employees, Employee appraisal and counseling and Mentoring/coaching employees were not significantly different across the public and private sectors, they were nevertheless ranked highly. Therefore they should be prioritized as a training need by both the Public and Private sectors.

Similar findings were obtained by Strong and Harder (2009) in a study of maintenance and motivation factors of agricultural extension agents who found that mentoring improved the proficiency in planning and implementing extension programs and in the comprehension of the workplace environment. Kuilek and Earnest (2001) reported that the outcome of extension employees partaking in a mentoring plan was an increase in their total leadership efficacy. Therefore the highest ranked competencies; Motivating employees, Stress management, Managing conflict, Management and administrative techniques, and Career development planning ought to be integrated and prioritised in the curriculum development and review programs and in-service staff development courses. 
Table 4: Comparison of Management and Leadership competencies needed by Public and Private Extension Agents

\begin{tabular}{|c|c|c|c|c|c|c|c|c|c|c|}
\hline \multirow{2}{*}{$\begin{array}{l}\text { Management and } \\
\text { leadership } \\
\text { competencies }\end{array}$} & \multicolumn{2}{|c|}{ MWDS } & \multicolumn{2}{|c|}{ Std. Dev } & \multicolumn{2}{|c|}{$\mathbf{N}$} & \multirow[t]{2}{*}{$t$} & \multirow{2}{*}{$\begin{array}{l}\text { Sig. } \\
2 \\
\text { tailed }\end{array}$} & \multirow{2}{*}{$\begin{array}{c}\text { Mann- } \\
\text { Witney } \\
\text { U test } \\
Z \\
\text { Statistic }\end{array}$} & \multirow{2}{*}{$\begin{array}{c}\text { Asymp. } \\
\text { Sig. } \\
2 \\
\text { tailed }\end{array}$} \\
\hline & Public & Private & Public & Private & Public & Private & & & & \\
\hline Stress management & 6.99 & 6.00 & 5.12 & 5.77 & 250 & 72 & 1.40 & 0.16 & -1.26 & 0.21 \\
\hline Motiva & 6.85 & & 5.51 & 4.97 & 225 & 71 & 0.45 & 0.65 & -0.48 & 0.63 \\
\hline Strategic planning & 6.60 & 4.87 & 5.41 & 5.39 & 253 & 83 & 2.53 & $0.01^{*}$ & -2.73 & $0.01^{*}$ \\
\hline Managing conflict & 6.54 & 5.37 & 5.02 & 5.48 & 248 & 82 & 1.80 & 0.07 & -1.77 & 0.08 \\
\hline $\begin{array}{l}\text { Management and } \\
\text { administrative techniques }\end{array}$ & 6.30 & 5.00 & 4.95 & 4.50 & 245 & 77 & 2.06 & $0.04^{*}$ & -1.82 & 0.07 \\
\hline $\begin{array}{l}\text { Career development } \\
\text { planning }\end{array}$ & 6.28 & 4.65 & 5.42 & 4.88 & 242 & 67 & 2.23 & $0.03^{*}$ & -2.07 & 0.04 \\
\hline $\begin{array}{l}\text { Managing } \\
\text { finances/budgeting }\end{array}$ & 6.11 & 5.03 & 4.90 & 4.90 & 248 & 84 & 1.76 & 0.08 & -1.54 & 0.12 \\
\hline $\begin{array}{l}\text { Balancing } \\
\text { personal/professional life }\end{array}$ & 5.63 & 5.36 & 5.07 & 4.32 & 245 & 65 & 0.40 & 0.70 & -0.02 & 0.99 \\
\hline Problem solving & 5.50 & 4.73 & 4.30 & 3.72 & 233 & 79 & 1.42 & 0.16 & -1.45 & 0.15 \\
\hline $\begin{array}{l}\text { Employee appraisal and } \\
\text { counselling }\end{array}$ & 5.32 & 5.80 & 4.81 & 5.78 & 247 & 77 & 0.72 & 0.47 & -0.34 & 0.73 \\
\hline $\begin{array}{l}\text { Maintaining ethical } \\
\text { standards }\end{array}$ & 5.31 & 4.22 & 4.31 & 4.45 & 210 & 66 & 1.78 & 0.08 & 1.70 & 0.09 \\
\hline Decisic & 5.27 & 4.46 & 3.82 & 4.33 & 219 & 71 & 1.49 & 0.14 & -1.72 & 0.09 \\
\hline Negotic & 5.11 & 4.56 & 4.35 & 3.76 & 236 & 63 & 0.91 & 0.37 & -0.37 & 0.71 \\
\hline Prioritizing work & 4.96 & 4.36 & 4.30 & 4.12 & 215 & 67 & 1.01 & 0.32 & -1.05 & 0.29 \\
\hline $\begin{array}{l}\text { Mentoring/coaching } \\
\text { employees }\end{array}$ & 4.80 & 5.25 & 4.52 & 4.76 & 237 & 70 & 0.72 & 0.47 & -0.72 & 0.47 \\
\hline $\begin{array}{l}\text { Community leadership } \\
\text { development }\end{array}$ & 4.76 & 4.49 & 4.12 & 3.94 & 240 & 75 & 0.50 & 0.62 & -0.30 & 0.76 \\
\hline Inter-agency collaboration & 4.44 & 4.22 & 4.00 & 3.68 & 239 & 72 & 0.42 & 0.68 & -0.21 & 0.84 \\
\hline Time management & 4.32 & 4.41 & 3.81 & 3.88 & 205 & 64 & 0.17 & 0.87 & -0.70 & 0.49 \\
\hline Team building & 4.19 & 3.87 & 3.79 & 3.63 & 235 & 75 & 0.64 & 0.52 & -0.56 & 0.58 \\
\hline Leadership skills & 3.96 & 4.03 & 3.45 & 3.82 & 231 & 75 & 0.15 & 0.88 & -0.94 & 0.35 \\
\hline Delegating responsibility & 3.76 & 3.63 & 3.86 & 3.78 & 229 & 70 & 0.23 & 0.82 & -0.39 & 0.70 \\
\hline
\end{tabular}

\section{Comparison of Management and Leadership for FEW and SMS}

A comparison of MWDS ratings for FEW and SMS is presented in Table 5. The findings show no significant differences in the MWDS ratings between the FEW and SMS for management and Leadership competencies except in Managing finances/budgeting with FEW expressing higher training needs. This could be attributed to SMS having more experience at managerial level and training at the undergraduate level as opposed to FEW who are diploma holders. Despite the lack of significance, the relatively high MWDS ratings are an indication of equal importance accorded to these competencies by both groups of respondents. This concurs with the findings of Strong and Hardy (2009)who found that Management skills such as teamwork, conflict resolution, decision making, giving credit, fairness, and delegation were ranked higher for the county supervisors (SMS) than county agents (FEW) . However the expressed management training need by FEW shows that the management skills are not a preserve of senior management but skills necessary for effective extension work at the interface with farmers.

The decentralization of extension service provision further emphasizes the need for extension staff to have management skills at all levels. These findings concur with Gibson and Schwarz (2010) in which extension agents (FEW) and specialists (SMS) identified understanding the interactions of individuals within groups and how people are motivated as their greatest continuing education and training need. All carders of extension staff identified the development of leadership abilities as most necessary for effective extension work (Gibson and Schwarz, 2010). Engagement with communities and stakeholders is a key tenet in the paradigm shift toward pluralism, demand driven 
and community based extension and Table 5 shows that Community leadership, Inter-agency collaboration/partnership, Team Building and Leadership skills that are necessary in working with stakeholders were also considered important by both FEW and SMS. Despite there being no significant differences, the relatively high MWDS warrants training in management and leadership competencies for both cadres of staff.

Table 5: Comparison of Management and Leadership competencies for FEW and SMS

\begin{tabular}{|c|c|c|c|c|c|c|c|c|c|c|c|}
\hline & \multirow{2}{*}{$\begin{array}{l}\text { Management and } \\
\text { leadership } \\
\text { competencies }\end{array}$} & \multicolumn{2}{|c|}{ MWDS } & \multicolumn{2}{|c|}{ Std. Dev } & \multicolumn{2}{|c|}{$\mathrm{N}$} & \multirow[t]{2}{*}{$t$} & \multirow{2}{*}{$\begin{array}{l}\text { Sig. } \\
(2- \\
\text { tailed) }\end{array}$} & \multirow[b]{2}{*}{$\begin{array}{c}\text { Mann- } \\
\text { Witney } \\
\text { U test } \\
Z \\
\text { statistic }\end{array}$} & \multirow{2}{*}{$\begin{array}{l}\text { Asymp. } \\
\text { Sig. } \\
(2- \\
\text { tailed) }\end{array}$} \\
\hline & & FEW & SMS & FEW & SMS & FEW & SMS & & & & \\
\hline \multirow{3}{*}{$\begin{array}{l}1 . \\
2 .\end{array}$} & Motivating employees & 7.18 & 6.17 & 5.97 & 4.34 & 176 & 120 & 1.60 & 0.11 & -1.18 & 0.24 \\
\hline & Stress management & 7.11 & 6.25 & 5.63 & 4.66 & 195 & 127 & 1.43 & 0.16 & -1.27 & 0.21 \\
\hline & $\begin{array}{l}\text { Managing } \\
\text { finances/budgeting }\end{array}$ & 6.34 & 5.12 & 5.54 & 3.74 & 196 & 136 & 2.23 & $0.03^{*}$ & -1.49 & 0.14 \\
\hline \multirow{2}{*}{$\begin{array}{l}3 . \\
4 .\end{array}$} & Strategic planning & 6.30 & 5.98 & 5.96 & 4.61 & 201 & 135 & 0.53 & 0.60 & -0.34 & 0.73 \\
\hline & $\begin{array}{l}\text { Career development } \\
\text { planning }\end{array}$ & 6.30 & 5.44 & 5.90 & 4.46 & 176 & 133 & 1.41 & 0.16 & -0.84 & 0.40 \\
\hline 5. & $\begin{array}{l}\text { Management and } \\
\text { administrative techniques }\end{array}$ & 6.28 & 5.57 & 5.11 & 4.48 & 190 & 132 & 1.29 & 0.20 & -0.88 & 0.38 \\
\hline \multirow{2}{*}{$\begin{array}{l}6 . \\
7 .\end{array}$} & Managing conflict & 6.16 & 6.39 & 5.44 & 4.70 & 200 & 130 & -0.38 & 0.70 & -0.77 & 0.44 \\
\hline & $\begin{array}{l}\text { Balancing } \\
\text { personal/professional life }\end{array}$ & 5.63 & 5.59 & 5.57 & 3.84 & 181 & 129 & -0.05 & 0.96 & -0.91 & 0.37 \\
\hline 8. & $\begin{array}{l}\text { Employee appraisal and } \\
\text { counselling }\end{array}$ & 5.47 & 5.39 & 5.21 & 4.80 & 198 & 126 & 0.14 & 0.90 & -0.24 & 0.81 \\
\hline 9. & $\begin{array}{l}\text { Maintaining ethical } \\
\text { standards }\end{array}$ & 5.40 & 4.57 & 4.62 & 3.94 & 160 & 116 & 1.57 & 0.12 & -1.56 & 0.12 \\
\hline 10. & Problem solving & 5.17 & 5.49 & 4.40 & 3.88 & 182 & 130 & -0.66 & 0.51 & -1.07 & 0.28 \\
\hline 11. & Prioritizing work & 5.14 & 4.37 & 4.80 & 3.36 & 163 & 119 & 1.49 & 0.14 & -0.96 & 0.34 \\
\hline \multirow{2}{*}{$\begin{array}{l}12 . \\
13 .\end{array}$} & Decision making & 5.01 & 5.15 & 4.27 & 3.50 & 168 & 122 & -0.30 & 0.77 & -0.51 & 0.61 \\
\hline & $\begin{array}{l}\text { Mentoring/coaching } \\
\text { employees }\end{array}$ & 5.01 & 4.75 & 5.07 & 3.72 & 183 & 124 & 0.49 & 0.62 & -0.09 & 0.93 \\
\hline \multirow{2}{*}{$\begin{array}{l}14 . \\
15 .\end{array}$} & Negotiation skills & 4.72 & 5.43 & 4.53 & 3.70 & 183 & 116 & -1.40 & 0.16 & -1.60 & 0.11 \\
\hline & $\begin{array}{l}\text { Community leadership } \\
\text { development }\end{array}$ & 4.42 & 5.14 & 4.51 & 3.24 & 192 & 123 & -1.54 & 0.13 & -1.83 & 0.07 \\
\hline 16. & $\begin{array}{l}\text { Inter-agency } \\
\text { collaboration/partnership }\end{array}$ & 4.38 & 4.41 & 4.24 & 3.47 & 178 & 133 & -0.08 & 0.93 & -0.15 & 0.88 \\
\hline 17. & Time management & 4.32 & 4.38 & 4.07 & 3.45 & 157 & 112 & -0.13 & 0.90 & -0.24 & 0.81 \\
\hline 18. & Team building & 3.91 & 4.43 & 4.15 & 3.01 & 190 & 120 & -1.19 & 0.23 & -1.30 & 0.19 \\
\hline 19. & Leadership skills & 3.80 & 4.24 & 3.86 & 3.01 & 182 & 124 & -1.07 & 0.29 & -1.01 & 0.31 \\
\hline 20. & Delegating responsibility & 3.65 & 3.84 & 4.04 & 3.53 & 179 & 120 & -0.41 & 0.69 & -0.36 & 0.72 \\
\hline
\end{tabular}

\section{Competencies in Agricultural Extension and Extension Management}

Using a critical incident questionnaire, the respondents were asked to narrate effective and ineffective extension activities they had undertaken within the last six months and identify extension management competencies that led to successful or ineffectiveness of the activity. The results are presented in Table 6. Effective communication, farmer group formation and data collection and analysis were the competencies that contributed highly to effective extension work. The competencies that were perceived to contribute to ineffective extension incidences were; inadequate skills in communication, public relations and farmer group formation. Team work, Conflict management/negotiation skills and Leadership were management competencies that contributed most to effective extension activities. Inadequate conflict management/negotiation skills, leadership and Information Communication and Technology (ICT) skills contributed most to ineffective management incidences. These courses ought to be included and development of these competencies integrated in the curricula. 
Table 6: Competence in Agricultural Extension and Extension Management

\begin{tabular}{|c|c|c|c|c|c|}
\hline & \multirow[t]{3}{*}{ Behaviours } & \multicolumn{4}{|c|}{ Frequency and Percentage of Behaviour } \\
\hline & & \multicolumn{2}{|c|}{ Effective } & \multicolumn{2}{|c|}{ Ineffective } \\
\hline & & $f$ & $\%$ & $f$ & $\%$ \\
\hline & Agricultural Extension & & & & \\
\hline 1. & Effective communication, telephone, written, public speaking & 79 & 21.0 & 54 & 22.0 \\
\hline 2. & Farmer group formation & 41 & 10.9 & 17 & 6.9 \\
\hline 3. & Data collection and analysis & 25 & 6.6 & 11 & 4.5 \\
\hline 4. & Program planning & 24 & 6.4 & 14 & 5.7 \\
\hline 5. & Extension methods & 23 & 6.1 & 5 & 2.0 \\
\hline 6. & Monitoring and Evaluation & 21 & 5.6 & 8 & 3.3 \\
\hline 7. & In-put provision & 18 & 4.8 & 9 & 3.7 \\
\hline 8. & Group dynamics & 17 & 4.5 & 14 & 5.7 \\
\hline 9. & Presentation skills & 14 & 3.7 & 8 & 3.3 \\
\hline 10. & Public relations & 12 & 3.2 & 18 & 7.3 \\
\hline 11. & Innovation management & 10 & 2.7 & 3 & 1.2 \\
\hline \multirow[t]{2}{*}{12.} & Gender roles and sensitization & 9 & 2.4 & 6 & 2.4 \\
\hline & $\begin{array}{l}\text { Sub total } \\
\text { Extension Management }\end{array}$ & 293 & 77.7 & 167 & 67.9 \\
\hline 1. & Team work & 21 & 5.6 & 9 & 3.7 \\
\hline 2. & Conflict management/negotiation skills & 17 & 4.5 & 21 & 8.4 \\
\hline 3. & Leadership & 17 & 4.5 & 18 & 7.3 \\
\hline 4. & Motivation & 15 & 4.0 & 12 & 4.9 \\
\hline 5. & Change management & 8 & 2.1 & 5 & 2.0 \\
\hline \multirow[t]{2}{*}{6.} & ICT & 6 & 1.6 & 14 & 5.7 \\
\hline & Sub-total & 84 & 22.3 & 79 & 32.1 \\
\hline \multicolumn{2}{|c|}{ Total } & 377 & 100.0 & 246 & 100.0 \\
\hline
\end{tabular}

\section{Conclusions and Recommendations}

Agricultural Extension Service is a people centred service and agriculture is a human driven activity. It is a dynamic industry requiring extension agents to cope with change and assist farmers understand and respond to changing consumer demands. The move toward privatization, demand-driven, grass-root, bottom-up approaches and decentralization has focused planning, implementation and coordination of extension activities at the district, divisional level and local level initiatives. This places greater responsibility on extension staff at this level.

Rural development encompasses more than extension education to focus on improved livelihoods of farming communities. It is a holistic development perspective of the farming community. The extension agent is no longer restricted to technical agricultural competencies but also to the wider social and economic context of agriculture. Competencies in extension management are important from four perspectives. First, in the management of extension service programs and projects, secondly in management of extension staff, and thirdly the management of networks, collaborations, and partnerships with stakeholders in the agriculture industry. Finally, but most importantly, in managing farmer relations to build trust and an enabling environment for effective extension service delivery. Effective communication is a key competency required for effective management. Interpersonal skills, social intelligence, presentation skills, public speaking and written communication and computer and technology aided communication are core communication competencies required by extension agents. There is therefore need for more emphasis in holistic training in non-technical areas and social competencies to achieve the objectives of Vision 2030 for the sector.

It is therefore recommended that Extension management competencies based on participatory methodologies in Needs Identification, Strategic planning, Implementation, Monitoring and Evaluation of extension programs and projects be incorporated in the undergraduate agricultural curricula. Basic management and administrative skills such as planning, organizing, directing, staffing, control and organizational change are necessary to impart competencies in organizational management. Human resource management competencies such as Career development planning, Motivating employees Employee appraisal and counseling Mentoring/coaching employees, Conflict management, Team Building and Leadership skills ought to be emphasized, integrated and prioritised in the undergraduate agricultural 
curricula and in the design of in-service staff development courses. This will ensure effective and efficient management of both human and physical resources in agricultural extension organizations

\section{References}

Cho, K.M. \& Boland, H. (2004). Agricultural Training in Myanmar: Extension Agents' Perceptions of Training Needs. Association for International Agricultural Education and Extension, Vol. 11 (1): 5-15.

Craig, M. (1992). Techniques for Investigation. In Handbook of Training and Development (p.1-27) Steve Truelove (Eds.), Blackwell Publishers, Oxford, UK.

Edwards, C.M. \& Briers, G.E. (1999). Assessing the In-service Needs of Entry-Phase Agriculture Teachers in Texas: A Discrepancy Model Versus Direct Assessment. Journal of Agricultural Education, 40(3): 40-49.

Ensle, K. M. (2005). Burnout: How does Extension balance job and family? Journal of Extension [On-line], 43(3) Article 3FEA5. Available at: http://www.joe.org/joe/2005june/a5.shtml

Fetsch, R. J., \& Kennington, M. S. (1997). Balancing work and family in Cooperative Extension: History, effective programs, and future directions. Journal of Extension [On-line], 35(1). Available at: http://www.joe.org/joe/1997february/a2.html

Flanagan, J.C. (1954). The critical incident technique. Psychological bulletin, 51(4), 327-358.

Gibson, J. \& Schwarz, M.H. (2010). A Needs Assessment of Aquaculture Extension Agents, Specialists, and Program Administrators in Extension Programming, Journal of Extension, 48 (2)

GoK - Government of the Republic of Kenya (2008). Ministry of Agriculture at a Glance. Ministry of Agriculture and Rural Development. Nairobi.

GoK - Government of the Republic of Kenya (2001). National Agricultural Extension Policy-(NAEP). Ministry of Agriculture and Rural Development. Nairobi.

GoK - Government of the Republic of Kenya (2004). Strategy for Revitalizing Agriculture (SRA), 2004-2014. Ministry of Agriculture and Ministry of Livestock and Fisheries development, March, 2004. Nairobi

GoK - Government of the Republic of Kenya (2005). National Agricultural Sector Extension Policy (NASEP); Ministry of Agriculture; Ministry of Livestock and Fisheries Development and Ministry of Cooperative Development and Marketing. December 2005. Nairobi

GoK - Government of the Republic of Kenya (2010). Agricultural Sector Development Strategy. 2010-2020 ASCU. Ministry of Agriculture. Nairobi.

Graham, D.L. \& Anita W. Cooper, A.W. (2001). Competencies Needed to be Successful County Agents and County Supervisors. Journal of Extension, 39 (1)

IFAD (2006). Evaluation Report on Agricultural Management Training in Africa (AMTA), IFAD.

Joerger, M.R. (2002). A Comparison of the In-service Education Needs of Two Cohorts of Beginning Minnesota Agricultural Education Teachers. Journal of Agricultural Education 43 (3): 11-24.

Kutilek, L. M., \& Earnest, G. W. (2001). Supporting professional growth through mentoring and coaching. Journal of Extension 39(4). Available at: http://www.joe.org/joe/2001august/rb1.html

Kutilek, L. M., Conklin, N. L., \& Gunderson, G. (2002). Investing in the future: Addressing work/life issues of employees. Journal of Extension 40(1). Available at: http://joe.org/joe/2002february/a6.html

Lindley, I.W. (1999). Constraints and Potentials of Training Mid-Career Extension Professionals in Africa Part 1and 2. International Workshop on Innovative Training Program for Mid-Career Agricultural Extension Field Staff in Sub-Saharan Africa, 6-8 July, Addis Ababa, Ethiopia.

Ministry of Agriculture and Rural Development (MOARD) (2002). Report on the Rationalizing and Staff Right Sizing. Ministry of Agriculture and Rural Development. Nairobi.

Mintzberg, H. (1973). The nature of managerial work. New York: Harper Row.

Sleezer, M.C., Kunneman, D. E., \& Key, P. J. (2000). Management Training Activities and Training Needs Within Selected Business and Industry Organizations in Oklahoma. Journal of Career and Technical Education, 16(2).

Strong, R. \& Harder, A. (2009). Implications of Maintenance and Motivation Factors on Extension Agent Turnover, Journal of Extension, $47(1)$

Swanson, B.E. (2008). Global Review of Good Agricultural Extension and Advisory Service Practices. Natural Resources Management and Environment Department and Policy Assistance and Resources, Mobilization Division Technical Cooperation Department. FAO. Rome.

Whiteside, M. (1998). Encouraging Sustainable Smallholder Agriculture in Southern Africa In The Context of Agricultural Services Reform Number 36, July, Overseas Development Institute Portland House Stag Place London SW1E 5DP, UK. 